\title{
Biomass, pigment production, and nutrient uptake of Chlorella sp. under different photoperiods
}

\author{
MUHAMMAD FAKHRI ${ }^{1,2, \boldsymbol{v}}$, ENDAR RIYANI ${ }^{1}$, ARNING WILUJENG EKAWATI ${ }^{1}$, NASRULLAH BAI ARIFIN ${ }^{1,2}$, \\ ATING YUNIARTI ${ }^{1,2}$, YUNI WIDYAWATI ${ }^{1,2}$, INDRA KURNIAWAN SAPUTRA ${ }^{3}$, PRATAMA DIFFI SAMUEL ${ }^{2,4}$, \\ MUHLIS ZAINUDIN ARIF ${ }^{5}$, ANIK MARTINAH HARIATI ${ }^{1,2}$ \\ ${ }^{1}$ Program of Aquaculture, Faculty of Fisheries and Marine Sciences, Universitas Brawijaya. J1. Veteran, Malang 65145, East Java, Indonesia. \\ Tel./fax.: +62-341-553512, "email: mfakhri@ub.ac.id \\ ${ }^{2}$ Aquatic Biofloc Research Group, Faculty of Fisheries and Marine Science, Universitas Brawijaya. J1. Veteran, Malang 65145, East Java, Indonesia \\ ${ }^{3}$ Program of Biotechnology, Faculty of Mathematics and Science, Universitas Negeri Malang. J1. Semarang, Malang 65145, East Java, Indonesia \\ ${ }^{4}$ Program of Aquatic Resources Management, Faculty of Fisheries and Marine Sciences, Universitas Brawijaya. Jl. Veteran, Malang 65145, East Java, Indonesia \\ ${ }^{5}$ Laboratory of Aquaculture, Faculty of Fisheries and Marine Sciences, Universitas Brawijaya. Jl. Veteran, Malang 65145, East Java, Indonesia
}

Manuscript received: 14 October 2021. Revision accepted: 13 November 2021.

\begin{abstract}
Fakhri M, Riyani E, Ekawati AW, Arifin NB, Yuniarti A, Widyawati Y, Saputra IK, Samuel PD, Arif MZ, Hariati AM. 2021. Biomass, pigment production, and nutrient uptake of Chlorella sp. under different photoperiods. Biodiversitas 22: 5344-5349. Chlorella sp. is well-known as a functional feed in fish culture and has been utilized in the food industry. In phototrophic cultivation, photoperiod plays a fundamental part in the growth and pigment content of microalgae. This work was purposed to evaluate the effect of light:dark cycle on the growth rate, production of biomass and pigment and nutrient utilization of Chlorella sp. Four photoperiods (8:16, 12:12, 18:6, and 24:0 h light:dark regimes) under a constant light intensity of 4500 lux were applied in this study. The results demonstrated that increasing light duration led to increased cell growth, biomass, and pigment production of Chlorella sp. The best cell concentration, specific growth rate, and biomass production were $28.5 \times 10^{6}$ cells $\mathrm{mL}^{-1}, 1.417 \mathrm{day}^{-1}$, and $0.815 \mathrm{~g} \mathrm{~L}^{-1}$ dry weight, respectively, under continuous illumination. The maximum chlorophyll $a$ of $19.205 \mathrm{mg} \mathrm{L}^{-1}$ and carotenoid of $4.695 \mathrm{mg} \mathrm{L}^{-1}$ were obtained at $24: 0 \mathrm{~h}$ photoperiod. The highest uptake of nitrate $(66.331 \%)$ and phosphate $(76.191 \%)$ by Chlorella sp. were achieved under $24 \mathrm{~h}$ light regime. Improving the uptake of nutrients resulted in enhanced growth and pigment content of Chlorella sp. We conclude that continuous illumination is the best photoperiod to produce biomass and pigment and improve the nutrient removal of Chlorella sp.
\end{abstract}

Keywords: Carotenoid, Chlorella, chlorophyll $a$, growth, nitrate, phosphate

\section{INTRODUCTION}

Microalgae are microorganism that has significant advantages such as rapid growth rate (Xu et al. 2019), high efficiency for photosynthesis process (Bohutskyi and Bouwer 2013), and able to assimilate nitrogen and phosphorus compounds from wastewater (Khan and Yoshida 2008). Microalgae have attracted tremendous interest because they can be used as a feedstock for generating biofuel, feeds (Benemann 2013), and synthesizing valuable chemicals such as protein, polyunsaturated fatty acids, and carbohydrates (Pignolet et al. 2013). Moreover, due to their significant amount of pigments, some microalgae species have been applied in the industry of cosmetics, food (Khanra et al. 2018), and aquaculture (Pignolet et al. 2013). In addition, chlorophyll $a$ and carotenoid are fundamental pigments for the photosynthetic process in microalgae (Johnson 2016).

The green microalga Chlorella sp. has been proposed as an essential feed source for farm animals and has commercially been applied in cosmetics and drugs (Sharma et al. 2012). This species produces valuable pigments such as chlorophyll (Griffiths et al. 2014), B-carotene (Seyfabadi et al. 2011; Fathi et al. 2013), and carotenoids (Yaakob et al. 2014; Safafar et al. 2016) which makes it potential for both natural feed and nutrient supplement for aquatic animals (Safafar et al. 2016). Moreover, Ahmad et al. (2018) explained that Chlorella biomass is commercially used for feed, growth enhancer, and immunostimulant in aquaculture.

The growth rate and nutritional profile of Chlorella are affected by environmental conditions, including $\mathrm{pH}$, salinity, temperature, and light (Sharma et al. 2012). Light is an elemental energy source in photoautotrophic cultivation (Wahidin et al. 2013). Light intensity, light quality, and photoperiod are known as key factors for photosynthetic activity and microalga growth (Singh and Singh 2015). Photoperiod is one of the critical conditions affecting the growth, biochemical profile, and physiological process of Chlorella (Khoeyi et al. 2012; Krzeminska et al. 2014). Chlorophyll and B-carotene content of microalgae are also influenced by altering the light and dark cycle (Seyfabadi et al. 2011). Moreover, the duration of the light can also affect the assimilation of nutrients by microalgae (Meseck et al. 2005).

The optimization of microalga biomass is a vital step to make the microalga culture feasible for mass scale. Therefore, understanding the characteristics of microalga species under different light regimes is indispensable (Bouterfas et al. 2006) to achieve an effective growth of 
Chlorella. Numerous research has been carried out to discover the influence of varying light cycle on the growth and nutritional composition of $C$. vulgaris (Seyfabadi et al. 2011; Khoeyi et al. 2012; Kendirlioglu et al. 2015; Levasseur et al. 2018). Additional information regarding how the duration of light affects the biomass and biochemical composition of Chlorella sp. is still interesting since microalgae's characteristics under different light conditions are strain-dependent (Banerjee et al. 2011). Moreover, the information regarding how different photoperiods influence the nutrient uptake in Chlorella sp. is still uncommon. This research was purposed to evaluate light and dark cycles on growth, biomass, and pigment production. In addition, this study analyzed how varying light regimes may influence the uptake of nitrate and orthophosphate by Chlorella $\mathrm{sp.}$

\section{MATERIALS AND METHODS}

\section{Microalgae and growth medium}

The freshwater green microalga Chlorella sp. FNUB001 (hereafter Chlorella sp., Figure 1) was applied to carry out this study. It was provided by the microalga collection of Laboratory of Aquaculture, Faculty of Fisheries and Marine Science, Universitas Brawijaya, Indonesia. Cells were cultured in a modified Walne medium using sterilized freshwater (Table 1) with the axenic condition. $1 \mathrm{~mL} \mathrm{~L}^{-1}$ of Walne solution and vitamin B12 were added to the medium.

\section{Experimental conditions}

A $2.5 \mathrm{~L}$ glass bottle was applied to grow Chlorella sp. under batch cultivation. Four different light and dark regimes used were 08:16, 12:12, 18:06, and 24:0 light/dark. Each light/dark regime was conducted in triplicate. The cool-white tubular lamp was applied as an artificial light source (cool white fluorescence tube lamp). The light intensity of 4500 lux was exposed to all culture bottles. Aeration was given continuously by air bubbling with $1 \mathrm{~L}$ minutes $^{-1}$ airflow and shaken manually once a day. The temperature of $28 \pm 2^{\circ} \mathrm{C}$ was kept during the experiment. Initial cell concentration and initial $\mathrm{pH}$ for all treatments were $5 \times 10^{5}$ cells $\mathrm{mL}^{-1}$ and 7.7 , respectively.

\section{Growth rate, doubling time, and biomass determination}

Cell counting using a Neubauer hemocytometer (BOECO, Hamburg, Germany) was utilized to determine microalga growth (Moheimani et al. 2013; Fakhri et al. 2015; Fakhri et al. 2017). Cell counts were taken daily. The following equations were applied to analyze the specific growth rate $(\mu)$ (Sakamoto et al. 2012) and doubling time (Td) (Xu et al. 2016) of Chlorella sp.:

$$
\mu\left(\text { day }^{-1}\right)=\frac{\ln \left(\mathrm{x}_{2}\right)-\ln \left(\mathrm{x}_{1}\right)}{\mathrm{t}_{2}-\mathrm{t}_{1}}
$$

$\operatorname{Td}($ hours) $=\ln 2 / \mu \times 24$
Table 1. Composition of Stock Modified Walne medium

\begin{tabular}{lc}
\hline \multicolumn{1}{c}{ Constituent } & Concentration $\left(\mathbf{g ~ L}^{-1}\right)$ \\
\hline $\mathrm{NH}_{4} \mathrm{NO}_{3}$ & 100.00 \\
$\mathrm{NaH}_{2} \mathrm{PO}_{4}$ & 20.00 \\
$\mathrm{H}_{3} \mathrm{BO}_{3}$ & 33.60 \\
$\mathrm{MnCl}_{2} \cdot \mathrm{H}_{2} \mathrm{O}$ & 0.36 \\
$\mathrm{FeCl}_{2}$ & 1.30 \\
$\mathrm{EDTA}$ & 45.00 \\
Vitamin B12 & 0.01 \\
\hline
\end{tabular}

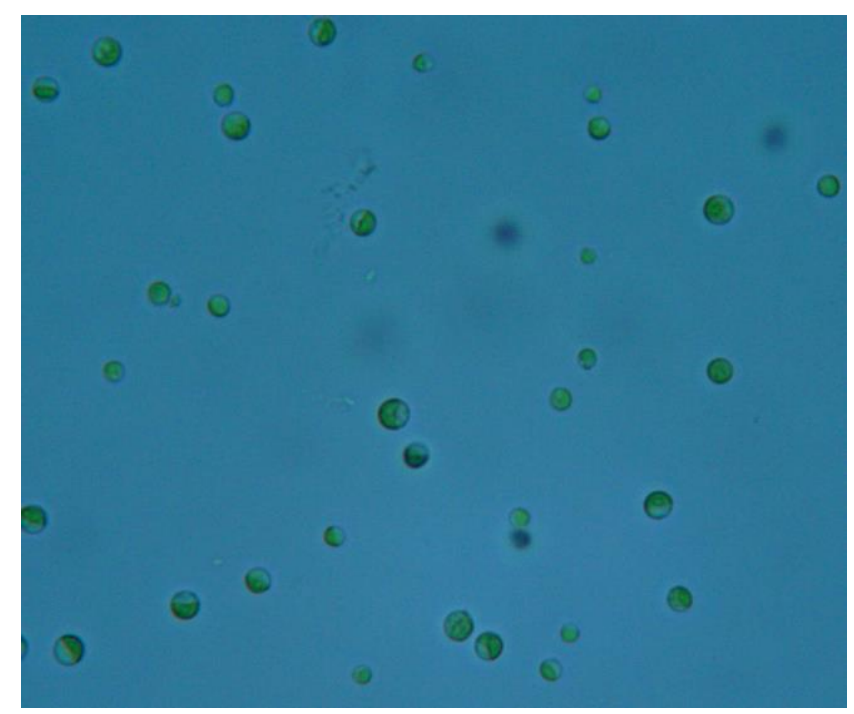

Figure 1. Morphology of Chlorella sp. FNUB001 cells under light microscope with 400x magnification

Biomass was analyzed as described by Janssen et al. (1999). Firstly, Whatman GF/C filter paper (diameter $9 \mathrm{~cm}$ ) was oven at $105^{\circ} \mathrm{C}$ for 2 hours and weighed until it was constant (A). On days 4 and 5 (when cells enter the stationary phase), $25 \mathrm{~mL}$ of culture was taken, and samples were filtered using filter paper $(\mathrm{GF} / \mathrm{C})$. Then, the algal pellet was incubated for 2 hours at $105^{\circ} \mathrm{C}$ and cooled in a desiccator. Finally, the dried algal and filter paper was weighed (B). Biomass concentration (dry weight, $\mathrm{g} \mathrm{L}^{-1}$ ) was quantified based on the following equation:

Biomass (dry weight, $\left.\mathrm{g} \mathrm{L}^{-1}\right)=(\mathrm{B}-\mathrm{A}) \times 1000 /$ Sample volume

\section{Pigment determination}

Microalgae at the stationary phase were used for pigment analysis. Firstly, $10 \mathrm{~mL}$ Chlorella suspension was centrifuged at $4032 \mathrm{~g}$-forces $(6000 \mathrm{rpm})$ for 10 minutes. For three cycles, cells were mechanically disrupted using the freezing and thawing method (frozen at $-20^{\circ} \mathrm{C}$ and thawed at room temperature). Then, the extract was mixed with $10 \mathrm{~mL}$ methanol absolute and followed by incubating at $70^{\circ} \mathrm{C}$ for 30 minutes in the water bath. The solution centrifugation was done at $4032 \mathrm{~g}$-forces for $10 \mathrm{~min}$ and the supernatant was kept for 24 hours at $4^{\circ} \mathrm{C}$ under dark conditions. Chlorophyll $a$ and carotenoid contents of 
supernatant were determined as reported by Ritchie (2006) and Kim et al. (2014) methods, respectively, using a spectrophotometer (Spectroquant Pharo300) at the wavelength of 480, 652, and $665 \mathrm{~nm}$.

$$
\begin{array}{ll}
\text { Chlorophyll } a\left(\mu \mathrm{g} \mathrm{mL}^{-1}\right) & =16.5169 \times \mathrm{A}_{665}-8.0962 \times \mathrm{A}_{652} \\
\text { Carotenoid }\left(\mu \mathrm{g} \mathrm{mL}^{-1}\right) & =4 \times \mathrm{A}_{480}
\end{array}
$$

\section{Nitrate and phosphate determination}

Nitrate and phosphate concentrations were measured at day 0 (for all photoperiods) and day 4 (for 06:18 and 12:12 light:dark cycle) and day 5 (for 18:06 and 24:00 light:dark cycle) of culture. $80 \mathrm{~mL}$ alga suspension was precipitated by centrifugation at $2800 \mathrm{~g}$-force $(5000 \mathrm{rpm})$ for 20 minutes, and the filtrate was used for nitrate and phosphate analysis. Firstly, for nitrate, $12.5 \mathrm{~mL}$ of filtrate was poured into a porcelain dish and heated until it formed a crust. Once the mixture cooled, $0.25 \mathrm{~mL}$ of phenoldisulfonic acid was supplemented. Then, the mixture was diluted with 5 $\mathrm{mL}$ of $\mathrm{H}_{2} \mathrm{O}$ and mixed with $\mathrm{NH}_{4} \mathrm{OH}$ until the color changed. Next, $\mathrm{H}_{2} \mathrm{O}$ was added to the mixture until it reached a volume of $12.5 \mathrm{~mL}$. Finally, the solution was determined spectrophotometrically at $410 \mathrm{~nm}$ (Boyd 1979). For phosphate, briefly, $25 \mathrm{~mL}$ of filtrate was added to $1 \mathrm{~mL}$ of ammonium molybdate. Then, the mixture was added with five drops of $\mathrm{SnCl}_{2}$ and homogenized. Finally, the mixture was read spectrophotometrically at $690 \mathrm{~nm}$ (Boyd 1979). Nitrate and phosphate concentrations were calculated from the standard curve prepared from standard nitrate and phosphate solutions, respectively.

Nutrient removal $\left(\mathrm{NO}_{3}{ }^{-}\right.$or $\left.\mathrm{PO}_{4}{ }^{3-}\right)$ was analyzed by calculating the difference of nutrient concentration within a culture period (mg L-1) (Osorio et al. 2020). The percentages of nutrient removal were quantified according to Acevedo et al. (2017) and Fakhri et al. (2021).

\section{Statistical analysis}

A significant difference in growth, biomass, pigment and nutrient removal among the four photoperiods was tested by ANOVA with levels of significance of $95 \%$. SPSS v.20.0 was applied for ANOVA.

\section{RESULTS AND DISCUSSION}

\section{Effect of photoperiod on growth and biomass production}

The growth pattern of Chlorella sp. cultured under different light regimes was demonstrated in Figure 2. The different photoperiods of 06:12, 12:12, 18:06, and 24:00 h were performed at a light intensity of 4500 lux. Two variations of the Chlorella sp. growth pattern were observed under different treatments of photoperiod. Cells cultivated under 18 and $24 \mathrm{~h}$ light cycles reach the maximum cell concentration on day 6 , while cells cultured under 6 and $12 \mathrm{~h}$ light cycles achieve the maximum cell concentration on day 5 . It means that photoperiods with more extended periods of light (18L:6D and 24L:0D) grew for longer days than in shorter periods of light. Khoeyi et al. (2012) reported that different growth pattern was also observed under different photoperiods in Chlorella vulgaris culture. In contrast to our result, they found that cells grew for a longer period in $12 \mathrm{~L}: 12 \mathrm{D}$ than in $16 \mathrm{~L}: 8 \mathrm{D}$. We suggested that different species have a specific response to various duration of light regimes.

We found a significant difference in growth rate, doubling time, and maximum cell concentration of Chlorella sp. under four photoperiods $(\mathrm{p}<0.05)$. The maximum cell concentration of $28.5 \times 10^{6}$ cells $\mathrm{mL}^{-1}$ and specific growth rate of 1.417 day $^{-1}$ were observed under continuous illumination (Table 2). Table 2 also shows that increasing the light cycle led to an increase in the specific growth rate and maximum cell concentration and reduced the doubling time of Chlorella sp. with the shortest time of 11.776 hours under a 24-h light cycle. Chlorella sp. cultured under 24:0 light cycle showed approximately two times higher growth rate and 4.6 times higher maximum cell concentration than that of 06:18 light cycle. These results agreed with $\mathrm{Xu}$ et al. (2016), who reported the best growth rate and cell concentration were achieved under 24 h light regime. Fakhri et al. (2015) also reported that the longer microalgae were exposed to light, the higher growth rate and cell concentration were produced. We suggested that there was no photoinhibition was observed under continuous light.

The result of Chlorella sp. biomass production under different photoperiods is shown in Figure 3. It was noticed that light duration remarkably affected the Chlorella sp. biomass production. Overall, the dry weight of Chlorella sp. cultured in the continuous light cycle $\left(0.815 \pm 0.022 \mathrm{~g} \mathrm{~L}^{-}\right.$ $\left.{ }^{1}\right)$ was $78.7 \%$ higher than those cultured in $12 \mathrm{~h}$ light cycles $\left(0.173 \pm 0.016 \mathrm{~g} \mathrm{~L}^{-1}\right)$. The lowest biomass concentration of cells was $0.112 \pm 0.004 \mathrm{~g} \mathrm{~L}^{-1}$ under six h light regime. These results are consistent with Khoeyi et al. (2012), who also found that biomass production of $C$. vulgaris increased with enhancing light duration. Similar results were also observed in Niangoran et al. (2021), who reported the biomass of Spirulina platensis increased with increasing light duration with the best photoperiod of 24 light regimes. Xue et al. (2011) explained that photo limitation is crucial for inhibiting microalga growth since the cells do not receive sufficient light. Singh and Singh (2015) explained that light is required to generate ATP and NADPH and produce important compounds for microalgae growth. In addition, Chauton et al. (2013) suggested low cell concentration and biomass production of microalgae under a long dark regime due to the cells not having adequate energy to promote the growth. Moreover, Jacob-Lopes et al. (2009) explained that light energy, which is received and stored in cells in the form of high-energy molecules (ATP and NADPH), is directly related to the capacity of carbon-fixation and, consequently, determining the cell metabolism and biomass concentration of microalgae. 


\begin{tabular}{cccc}
\hline Photoperiod (L:D regime) $\mathbf{h}$ & Maximum specific growth rate (day $\left.{ }^{-1}\right)$ & Doubling time (hours) & $\begin{array}{c}\text { Maximum cell concentration } \\
\left(\mathbf{x ~ 1 0} \mathbf{~ c e l l s ~ m L ~}^{-1}\right)\end{array}$ \\
\hline $06: 18$ & $0.740 \pm 0.027^{\mathrm{a}}$ & $22.514 \pm 0.813$ & $6.125 \pm 0.530^{\mathrm{a}}$ \\
$12: 12$ & $0.867 \pm 0.010^{\mathrm{b}}$ & $19.198 \pm 0.200$ & $9.875 \pm 0.530^{\mathrm{b}}$ \\
$18: 06$ & $1.324 \pm 0.030^{\mathrm{c}}$ & $12.568 \pm 0.288$ & $22.375 \pm 0.884^{\mathrm{c}}$ \\
$24: 00$ & $1.417 \pm 0.089^{\mathrm{d}}$ & $11.776 \pm 0.764$ & $28.500 \pm 0.471^{\mathrm{d}}$ \\
\hline
\end{tabular}

Note: Means with different superscript letters are significantly different $(\mathrm{P}<0.05)$

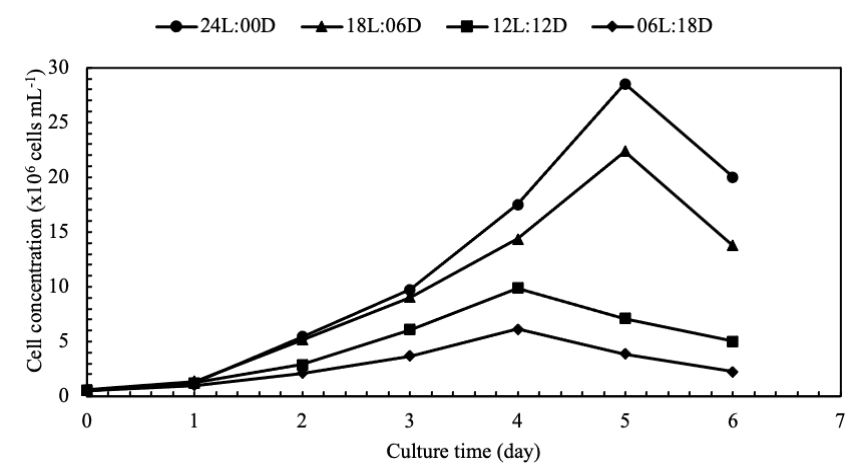

Figure 2. Cell concentration of Chlorella sp. under different light:dark cycles during the culture period

\section{Effect of photoperiod on chlorophyll $a$ and carotenoid content}

The pigment content of cultured Chlorella sp. under varying photoperiods is summarized in Table 3. Cells' pigment was remarkably influenced by the light cycle $(p<0.05)$. It was observed that longer light duration increased the chlorophyll $a$ and carotenoid production of Chlorella sp. Overall, the production of chlorophyll $a$ and carotenoid of Chlorella sp. under continuous illumination showed roughly $66 \%$ and $60 \%$ higher than that in the 12L:12D light cycle, respectively. Fakhri et al. (2017) reported that the maximum production of chlorophyll $a$ and carotenoid of Nannochloropsis sp. BJ17 was achieved under continuous illumination. A similar profile was also observed in Fábregas et al. (2002) study, who found that the chlorophyll $a$ and carotenoid production increased when $N$. gaditana was exposed to long light duration. In contrast to our results, Kendirlioglu et al. (2015) addressed that the maximum amount of chlorophyll and carotenoid of C. vulgaris was produced under a $16 \mathrm{~h}$ light regime.

In this study, the high chlorophyll $a$ content under continuous illumination is probably associated with the enhancing number of photosynthetic units during light harvesting (Yusof et al. 2021). Furthermore, enhancing carotenoid content under a $24 \mathrm{~h}$ light regime is related to the function of carotenoids in the photosynthesis process, which is to alleviate and assist the pigment-protein complex in the thylakoid membrane (Takaichi 2011; Yusof et al. 2021). Variation of photoperiods had a different effect on the pigment content of microalgae, and it is probably dependent on the adaptation of cells to the different environments (Kendirlioglu et al. 2015; Fakhri et al. 2017; Niangoran et al. 2021).

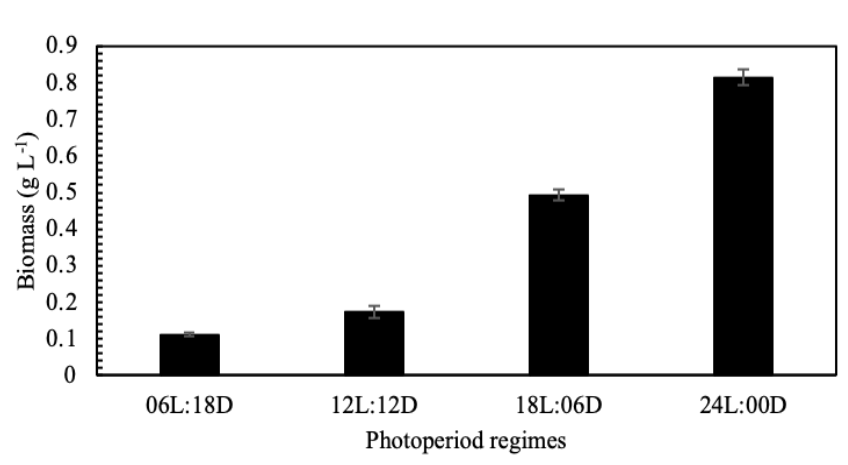

Figure 3. Biomass concentration of Chlorella sp. under different light:dark cycles

\section{Effect of photoperiod on nitrate and phosphate uptake}

In this study, initial nitrate and phosphate concentrations were $77.50 \mathrm{mg} \mathrm{L}^{-1}$ and $15.83 \mathrm{mg} \mathrm{L}^{-1}$, respectively. The results of nitrate and phosphate uptake of Chlorella sp. under different light regimes are displayed in Figures 4 and 5, respectively. From these figures, we can see that increasing light duration enhanced the nutrient uptake by Chlorella sp. The highest nitrate removal $(66.331 \%)$ was observed in the 24L:0D light cycle, while the lowest nitrate removal $(33.522 \%)$ was observed in the 06L:18D light cycle. These results revealed that long light duration increased the metabolic requirement of nitrogen and phosphorus by Chlorella sp. A similar profile was discovered for phosphate removal, with the maximum reduction of $76.191 \%$ was obtained in the 24L:0D light cycle, while the lowest phosphate removal of $28.171 \%$ was obtained in the 06L:18D light cycle. Liu et al. (2019) reported that increasing photoperiod enhanced the nitrogen and phosphorus uptake of photosynthetic bacteria. Zhi et al. (2019) also showed that the highest nitrogen and phosphorus utilization were observed under continuous illumination.

Interestingly, the nutrient uptake is linearly correlated to growth rate, biomass concentration, and pigment content in this study. In addition, the higher cells utilized the nutrient, and the more significant cells produced the biomass and pigment. A similar phenomenon was found that increasing nutrient uptake resulted in increased growth, biomass yield, and pigment content of Dunaliella sp. (Fakhri et al. 2021). Yaakob et al. (2021) also observed that increasing phosphate utilization produces high microalgae growth and biomass yield. 


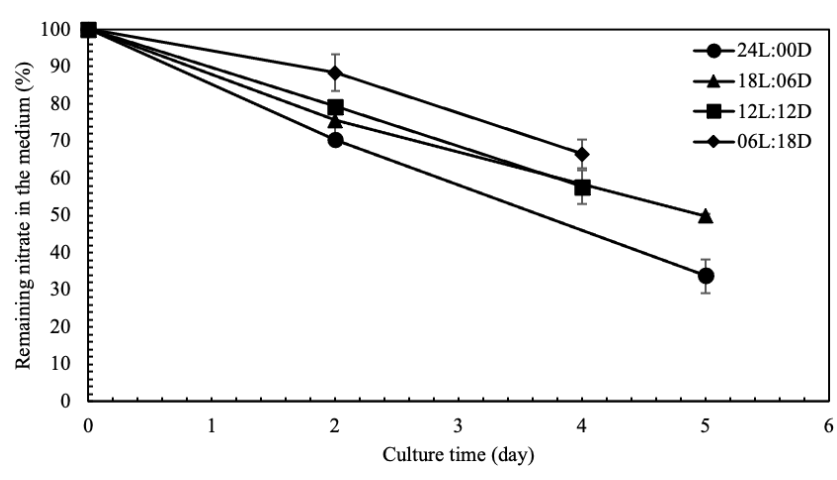

Figure 4. Nitrate uptake by Chlorella sp. under different photoperiods

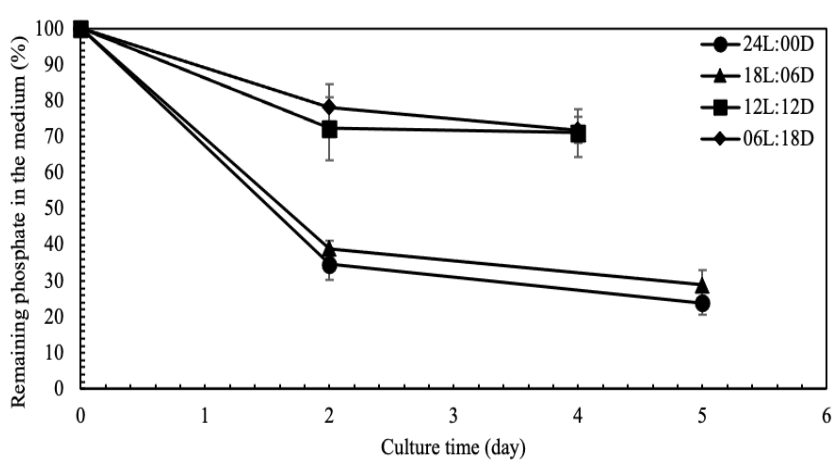

Figure 5. Phosphate uptake by Chlorella sp. under different photoperiods

Table 3. Chlorophyll $a$ and carotenoid content of Chlorella sp. under different photoperiods

\begin{tabular}{ccc}
\hline $\begin{array}{c}\text { Photoperiod } \\
(\mathbf{L}: D \text { regime }) \mathbf{h}\end{array}$ & $\begin{array}{c}\text { Chlorophyll } \boldsymbol{a} \\
\left(\boldsymbol{\mu g} \mathbf{~ m L}^{-1}\right)\end{array}$ & $\begin{array}{c}\text { Carotenoid } \\
\left(\boldsymbol{\mu g} \mathbf{~ m L}^{-1}\right)\end{array}$ \\
\hline $06: 18$ & $2.421 \pm 0.030^{\mathrm{a}}$ & $0.717 \pm 0.030^{\mathrm{a}}$ \\
$12: 12$ & $6.456 \pm 0.100^{\mathrm{b}}$ & $1.865 \pm 0.040^{\mathrm{b}}$ \\
$18: 06$ & $13.648 \pm 0.620^{\mathrm{c}}$ & $3.528 \pm 0.061^{\mathrm{c}}$ \\
$24: 00$ & $19.205 \pm 1.048^{\mathrm{d}}$ & $4.695 \pm 0.038^{\mathrm{d}}$ \\
\hline
\end{tabular}

Means with different superscript letters are significantly different $(\mathrm{P}<0.05)$

Nitrogen plays an essential part in microalgal culture because it is the key element for proteins, chlorophylls, and DNA synthesis (Pancha et al. 2014). Zarrinmehr et al. (2020) explained that nitrogen regulates microalga growth and biomass. Besides, phosphorus is one of the major components for microalga growth and has a fundamental role in ATP production for energy metabolism (Chen and Chen 2006). The inorganic phosphate is involved in the regulation of enzyme activity, biochemical pathways, and the biological transport system, as well as influencing the photosynthesis process (Mimura 1995; Benavente-Valdés et al. 2016). Kujawinski et al. (2017) indicated that the availability of phosphorus influences intracellular nucleotide pools in microalgae and, as a result, affects their growth and biomass production.
In conclusion, it has been shown from this study that photoperiod exhibits an essential role in influencing the growth, biomass, pigment production, and nutrient removal of Chlorella sp. Enhancing light cycle exposure increased the growth and biomass production of Chlorella sp. The highest pigment content of Chlorella sp. was observed under continuous illumination. In addition, increasing light duration led to improving the nutrient uptake by Chlorella sp. When cells are exposed to a long dark regime, the cells cannot uptake the nutrient. Therefore, increasing nutrient utilization leads to higher growth, biomass, and pigment content of Chlorella sp.

\section{ACKNOWLEDGEMENTS}

The authors are thankful for financial support from Faculty of Fisheries and Marine Sciences, Universitas Brawijaya, Indonesia.

\section{REFERENCES}

Acevedo S, Pino NJ, Peñuela GA. 2017. Biomass production of Scenedesmus sp. and removal of nitrogen and phosphorus in domestic wastewater. Ingeniería y Competitividad 19: 185-193.

Ahmad MT, Shariff M, Yusoff FMd, Goh YM, Banerjee S. 2018. Applications of microalga Chlorella vulgaris in aquaculture. Rev Aquac 12 (1): 328-346. DOI: 10.1111/raq.12320.

Banerjee S, Hew WE, Khatoon H, Shariff M, Yusoff FMd. 2011. Growth and proximate composition of tropical marine Chaetoceros calcitrans and Nannochloropsis oculata cultured outdoors and under laboratory $\begin{array}{lllll}\text { conditions. Afr J Biotechnol } 10 & \text { (8): 1375-1383. DOI: }\end{array}$ 10.5897/AJB10.1748.

Benavente-Valdés JR, Aguilar C, Contreras-Esquivel JC, Méndez-Zavala A, Montañez J. 2016. Strategies to enhance the production of photosynthetic pigments and lipids in chlorophycae species. Biotechnol Rep 10: 117-125. DOI: 1016/j.btre.2016.04.001.

Benemann J. 2013. Microalgae for biofuels and animal feeds. Energies 6 (11): 5869-5886. DOI: 10.3390/en6115869.

Bohutskyi P, Bouwer E. 2013. Biogas production from algae and cyanobacteria through anaerobic digestion: A review, analysis, and research needs. In: Lee JW (eds). Advanced Biofuels and Bioproducts. Springer, New York.

Bouterfas R, Belkoura M, Dauta A. 2006. The effects of irradiance and photoperiod on the growth rate of three freshwater green algae isolated from a eutrophic lake. Limnetica 25 (3): 647-656.

Boyd CE. 1979. Water Quality in Warmwater Fish Pond. Agricultural Experiment Station, Auburn University, USA.

Chauton MS, Winge P, Brembu T, Vadstein O, Bone AM. 2013 Gene regulation of carbon fixation, storage, and utilization in the Diatom Phaeodactylum tricornutum acclimated to light/dark cycles. Plant Physiol 161 (2): 1034-1048. DOI: 10.1104/pp.112.206177.

Chen GQ, Chen F. 2006. Growing phototrophic cells without light. Biotechnol Lett 28: 607-616. DOI: 10.1007/s10529-006-0025-4.

Fabregas J, Maseda A, Domínguez A, Ferreira M, Otero A. 2002. Changes in the cell composition of the marine microalga, Nannochloropsis gaditana, during a light: Dark cycle. Biotechnol Lett 24: 1699-1703. DOI: 10.1023/A:1020661719272.

Fakhri M, Arifin NB, Budianto B, Yuniarti A, Hariati AM. 2015. Effect of salinity and photoperiod on growth of microalgae Nannochloropsis sp. and Tetraselmis sp. Nat Environ Pollut Technol 14: 563-566.

Fakhri M, Arifin NB, Yuniarti A, Hariati AM. 2017. The influence of salinity on the growth and chlorophyll content of Nannochloropsis sp. BJ17. Nat Environ Pollut Technol 16: 209-212.

Fakhri M, Sanudi, Arifin NB, Ekawati AW, Yuniarti A, Hariati AM. 2017. Effect of photoperiod regimes on growth, biomass and pigment content of Nannochloropsis sp. BJ17. Asian J Microbiol Biotechnol Environ Sci 19: 263-267. 
Fakhri M, Antika PW, Ekawati AW, Arifin NB, Yuniarti A, Hariati AM. 2021. Effect of glucose administration on biomass, $\beta$-carotene and protein content of Dunaliella sp. under mixotrophic cultivation. Intl J Agric Biol 25: 404-408. DOI: 10.17957/IJAB/15.1681.

Fathi M, Meshkini S, Nadiri R. 2013. The effect of extracted salt from Urmia Lake on the growth, Beta-carotene and chlorophyll $a$ content of halophilic alga Chlorella sp. Turk J Fish Aquat Sci 13: 233-240. DOI: 10.4194/1303-2712-v13 205.

Griffiths MJ, van Hille RP, Harrison ST. 2014. The effect of nitrogen limitation on lipid productivity and cell composition in Chlorella vulgaris. Appl Microbiol Biotechnol 98 (5): 2345-2356. DOI: 10.1007/s00253-013-5442-4.

Jacob-Lopes E, Scoparo CHG, Lacerda LMCF, Franco TT. 2009. Effect of light cycles (night/day) on $\mathrm{CO}_{2}$ fixation and biomass production by microalgae in photobioreactors. Chem Eng Process 48 (1): 306-310. DOI: 10.1016/j.cep.2008.04.007.

Janssen M, Kuijpers TC, Veldhoen B, Ternbach MB, Tramper J, Mur LR, Wijffels RH. 1999. Specific growth rates of Chlamydomonas reinhardtii and Chlorella sorokiniana under medium duration light/dark cycles: 13-87s. J Biotechnol 70 (1-3): 323-333. DOI 10.1016/S0079-6352(99)80124-6.

Johnson MP. 2016. Photosynthesis. Essays Biochem 60 (3): 255-273. DOI: $10.1042 / \mathrm{EBC} 20160016$.

Kendirlioglu G, Agirman N, Cetin AK. 2015. The effects of photoperiod on the growth, protein amount and pigment content of Chlorella vulgaris. Turk J Sci Technol 10 (2): 7-10.

Khan M, Yoshida N. 2008. Effect of L-glutamic acid on the growth and ammonium removal from ammonium solution and natural wastewater by Chlorella vulgaris NTM06. Bioresour Technol 99 (3): 575-582. DOI: 10.1016/j.biortech.2006.12.031.

Khanra S, Mondal M, Halderl G, Tiwari ON, Gayen K, Bhowmick TK 2018. Downstream processing of microalgae for pigments, protein and carbohydrate in industrial application: A review. Food Bioprod Process 110: 60-84. DOI: 10.1016/j.fbp.2018.02.002.

Khoeyi ZA, Seyfabadi J, Ramezanpour Z. 2012. Effect of light intensity and photoperiod on biomass and fatty acid composition of the microalgae, Chlorella vulgaris. Aquac Intl 20 (1): 41-49. DOI: 10.1007/s10499-011-9440-1.

Kim CW, Sung MG, Nam K, Moon M, Kwon JH, Yang JW. 2014. Effect of monochromatic illumination on lipid accumulation of Nannochloropsis gaditana under continuous cultivation. Bioresour Technol 159: 30-35. DOI: 10.1016/j.biortech.2014.02.024.

Krzeminska I, Pawlik-Skowronska B, Trzcinska M, Tys J. 2014. Influence of photoperiods on the growth rate and biomass productivity of green microalgae. Bioprocess Biosyst Eng 37 (4): 735-741. DOI: 10.1007/s00449-013-1044-x.

Kujawinski EB, Longnecker K, Alexander H, Dyhrman ST, Fiore CL, Haley ST, Johnson WM. 2017. Phosphorus availability regulates intracellular nucleotides in marine eukaryotic phytoplankton. Limnol Oceanogr Lett 2: 119-129. DOI: 10.1002/lol2.10043.

Levasseur W, Taidi B, Lacombe R, Perré P, Pozzobon V. 2018. Impact of seconds to minutes photoperiods on Chlorella vulgaris growth rate and chlorophyll $a$ and $b$ content. Algal Res 36: 10-16. DOI: 10.1016/j.algal.2018.10.007.

Liu S, Daiggerd GT, Kang J, Zhang G. 2019. Effects of light intensity and photoperiod on pigments production and corresponding key gene expression of Rhodopseudomonas palustris in a photobioreactor system. Bioresour Technol 294: 1-8. DOI: 10.1016/j.biortech.2019.122172.

Meseck SL, Alix JH, Wikfors GH. 2005. Photoperiod and light intensity effects on growth and utilization of nutrients by the aquaculture feed microalga, Tetraselmis chui (PLY429). Aquaculture 246 (1-4): 393404. DOI: 10.1016/j.aquaculture.2005.02.034.

Mimura T. 1995. Homeostasis and transport of inorganic phosphate in plants. Plant Cell Physiol 36: 1-7. DOI 10.1093/oxfordjournals.pcp.a078724.

Moheimani N, Borowitzka M, Isdepsky A, Sing SF. 2013. Standard methods for measuring growth of algae and their composition. In: Borowitzka MA, Moheimani NR (eds). Algae for Biofuels and Energy. Springer, Netherlands

Niangoran NUF, Buso D, Zissis G, Prudhomme T. 2021. Influence of light intensity and photoperiod on energy efficiency of biomass and pigment production of Spirulina (Arthrospira platensis). OCL 28: 18. DOI: $10.1051 / \mathrm{ocl} / 2021025$.

Osorio JHM, del Mondo A, Pinto G, Pollio A, Frunzo L, Lens PNL, Esposito G. 2020. Nutrient removal efficiency of green algal strains at high phosphate concentrations. Water Sci Technol 80 (10): 1832 1843. DOI: $10.2166 /$ wst.2019.431.

Pancha I, Chokshi K, George B, Ghosh T, Paliwal C, Maurya R, Mishra S. 2014. Nitrogen stress triggered biochemical and morphological changes in the microalgae Scenedesmus sp. CCNM 1077. Bioresour Technol 156: 146-154. DOI: 10.1016/j.biortech.2014.01.025.

Pignolet O, Jubeau S, Vaca-Garcia C, Michaud P. 2013. Highly valuable microalgae: Biochemical and topological aspects. J Ind Microbiol Biotechnol 40: 781-796. DOI: 10.1007/s10295-013-1281-7.

Ritchie RJ. 2006. Consistent sets of spectrophotometric chlorophyll equations for acetone, methanol and ethanol solvents. Photosynth Res 89: 27-41. DOI: 10.1007/s11120-006-9065-9.

Safafar H, Nørregaard PU, Ljubic A, Møller P, Holdt SL, Jacobsen C. 2016. Enhancement of protein and pigment content in two Chlorella species cultivated on industrial process water. J Mar Sci Eng 4 (4): 115. DOI: $10.3390 /$ jmse4040084.

Sakamoto K, Baba M, Suzuki I, Watanabe MM, Shiraiwa Y. 2012. Optimization of light for growth, photosynthesis, and hydrocarbon production by the colonial microalga Botryococcus braunii BOT-22. Bioresour Technol 110: 474-479. DOI: 10.1016/j.biortech.2012.01.091.

Seyfabadi J, Ramezanpour Z, Khoeyi ZA. 2011. Protein, fatty acid, and pigment content of Chlorella vulgaris under different light regimes. J Appl Phycol 23: 721-726. DOI: 10.1007/s10811-010-9569-8.

Sharma R, Singh GP, Sharma VK. 2012. Effects of culture conditions on growth and biochemical profile of Chlorella vulgaris. J Plant Pathol Microb 3 (5): 1-6. DOI: 10.4172/2157-7471.1000131.

Singh SP, Singh P. 2015. Effect of temperature and light on the growth of algae species: A review. Renew Sustain Energy Rev 50: 431-444. DOI: $10.1016 /$ j.rser.2015.05.024.

Takaichi S. 2011. Carotenoids in algae: Distributions, biosyntheses and functions. Mar Drugs 9: 1101-1118. DOI: 10.3390/md9061101.

Wahidin S, Idris A, Shaleh SR. 2013. The influence of light intensity and photoperiod on the growth and lipid content of microalgae Nannochloropsis sp. Bioresour Technol 129: 7-11. DOI: 10.1016/j.biortech.2012.11.032.

Xu K, Zou X, Wen H, Xue Y, Qu Y, Li Y. 2019. Effects of multitemperature regimes on cultivation of microalgae in municipal wastewater to simultaneously remove nutrients and produce biomass. Appl Microbiol Biotechnol 103 (19): 8255-8265. DOI: 10.1007/s00253-019-10051-6.

Xu Y, Ibrahim IM, Harvey PJ. 2016. The influence of photoperiod and light intensity on the growth and photosynthesis of Dunaliella salina (Chlorophyta) CCAP 19/30. Plant Physiol Biochem 106: 305-315. DOI: $10.1016 /$ j. plaphy.2016.05.021.

Xue C, Goh QY, Tan W, Hossain I, Chen WN, Lau R. 2011. Lumostatic strategy for microalgae cultivation utilizing image analysis and chlorophyll $a$ content as design parameters. Bioresour Technol 102 (10): 6005-6012. DOI: 10.1016/j.biortech.2011.02.061.

Yaakob MA, Mohamed RMSR, Al-Gheethi A, Gokare RA, Ambati RR. 2021. Influence of nitrogen and phosphorus on microalgal growth, biomass, lipid, and fatty acid production: An overview. Cells 10 (2): 1-19. DOI: $10.3390 /$ cells10020393.

Yaakob Z, Ali E, Zainal A, Mohamad M, Takriff MS. 2014. An overview: Biomolecules from microalgae for animal feed and aquaculture. $\mathrm{J}$ Biol Res (Thessalon) 21: 1-10. DOI: 10.1186/2241-5793-21-6.

Yusof NS, Yeong YS, Zakeri HA, Wahid MEA, Ghafar SNA, Yusuf N. 2021. Photoperiod influenced the growth and antioxidative responses of Chlorella vulgaris, Isochrysis galbana, and Tetraselmis chuii. J Appl Pharm Sci 11 (4): 125-134. DOI: 10.7324/JAPS.2021.110415.

Zarrinmehr MJ, Farhadian O, Heyrati FP, Keramat J, Koutra E, Kornaros M, Daneshvar E. 2020. Effect of nitrogen concentration on the growth rate and biochemical composition of the microalga, Isochrysis galbana. Egypt J Aquat Res 46 (2): 153-158. DOI: 10.1016/j.ejar.2019.11.003.

Zhi R, Yang A, Zhang G, Zhu Y, Meng F, Li X. 2019. Effects of lightdark cycles on photosynthetic bacteria wastewater treatment and valuable substances production. Bioresour Technol 274: 496-501. DOI: 10.1016/j.biortech.2018.12.021. 